Review article UDC 113:17.023(38)(091)

doi: $10.21464 / \mathrm{sp} 31103$

Received January $30^{\text {th }}, 2015$

\author{
Nihal Petek Boyaci Gülenç \\ İstanbul Medeniyet University, South Campus, Faculty of Arts and Humanities, Department of Philosophy, \\ B Building B-01-06 Dumlupınar Street, D-100, no. 98, TR-34710 Kadikoy, Istanbul \\ npetekb@gmail.com
}

\title{
An Enquiry on Physis-Nomos Debate: Sophists
}

\begin{abstract}
One of the main discussions related to the topic of the "human-made world" is the physisnomos debate. The historical roots of this debate can be traced back to the fifth and fourth centuries BCE. Many philosophers, historians, and authors revealed different ideas about this subject. Some of them considered physis to be superior to nomos, while others considered nomos to be superior to physis. The main problem that arises in this discussion is the inclination to stabilize the tension between these two concepts by drawing thick boundaries between them. In this respect, we need to ask two significant philosophical questions. Firstly, is it possible to say that physis and nomos have definite conceptual schemes? The second question is connected to the first one and it deals with whether the tension between physis and nomos can be handled in a fixed manner or not. This paper discusses these questions from the perspectives of the Sophists and contemporary thinkers involved in the physis-nomos debate. It will be based on the idea of how human beings think while constituting the world, and it will evaluate how physis and nomos ought to be related.
\end{abstract}

\section{Keywords}

nature, convention, law, universal, justice, pre-Sophists, Sophists

\section{Introduction}

There are two quite controversial philosophical concepts appearing since the second half of the fifth century BCE: physis and nomos. Human-made world debate is mostly discussed on the axis of these concepts as well. An enquiry into what basis people set up the world on inevitably requires the realization of thinking about this important debate that has been developing in the history of philosophy since the Sophists. Most of the time, questions such as what kind of nature-human being, and human being-human being relationships exist, how is it possible to live together in the context of a social platform, how to determine right and wrong in social life, and so on, drove philosophers and social scientists into thinking about physis and nomos. In this manner, in the fifth century BCE many philosophers, thinkers, and historians suggested different ideas on this subject. In the pursuit of detailed discussions on physis and nomos, some perceived nomos superior to physis, while others recognized physis as superior to nomos. Both tried to create a foundation for the establishment of the human world. So, what are physis and nomos? Can proper definitions of these two concepts formulate a clear framework? Is it really possible to address these concepts as opposed to each other?

In the context of the dictionary meaning, physis can be translated as 'nature', and nomos can be translated as 'law', 'convention' or 'custom'. Etymologi- 
cally, physis can be associated with the word $\varphi v \omega$ - the Sophists and pre-Socratic naturalists argued that the nature of things is unfolded in their origins, and in their productive power (Barney, 2006:84). Physis referred to the growth or emergence of an essence in a thing. Therefore, the word physis means 'origin', 'birth', 'growth' or 'natural form of a person and nature'. As was stated by Aristotle, the substance of everything is physis, and the thing, which is the source of motion, forms the substance of them (Kerferd, 1981:111). ${ }^{1}$

The origin of nomos derives from the term vé $\mu \omega$. This word, bearing a meaning 'to deal out', 'to dispense', 'to distribute', and 'to divide', can be viewed as an equal redistribution of rights to everyone. This fair distribution arises as a result of agreement between people. Nomos means 'usage', 'custom', 'statute', or 'ordinance' made by authority or law. As Taylor stated, nomos

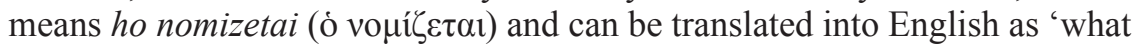
is customarily' (Taylor, 2007:1). Thus, due to this meaning, the word can be associated with the word vouí $\omega$ in terms of the origin, and it might mean 'I accept', 'I approve' or 'I believe' (Kerferd, 1981:112). Addressed within these semantic relations, nomos can be defined as a 'convention', 'opinion' or 'belief', an 'approved law', without bearing an essence. The fact that nomos is not essence-based emphasizes that it is valid within a certain time or place, or in some certain societies. Thus this notion has to be taken within this context, and, as such, it can be considered as a set of norms or habits that may vary from society to society. Therefore, a bond between people in a society established with nomos is conventional rather than essential.

In terms of thinking about these two concepts within the framework of these definitions, it is inevitable to consider physis as being universal/constant, and nomos as being local/contingent. Following these definitions, the basic distinction between physis and nomos and the basis of the debates developed in regard to both concepts can be grounded as follows. When we accept a nature or essence of something being an $x$, we accept that everything that comes into that something also has the same characteristics of that $x$. However, when providing cooperation in a sense of reconciliation of something, this cooperation is neither valid for all times nor for everything that exists. On the other hand, nomos in general sense is the thing that is agreed on in a certain place, and maintains its validity within a certain period of time. Addressing these concepts as opposed points us towards the tension between being universal and being local. In terms of establishing a human world that is changing within, the formula for living together in a fair manner generally focuses on a universal being, and that shift constitutes the main axis of the debate. Can rules or universal principles, which may apply to everyone, be created either with nomos or with physis? How accurately can we explain concepts of nomos and physis in the ways described above and can these concepts really be handled in a way we expressed them so far? Do individuals who prefer physis to nomos or nomos to physis find different purposes in doing so? Now, let us try to look for answers to these questions in terms of different approaches regarding the subject.

\section{Physis and nomos in the pre-Sophists period}

In the review of the Presocratic period, we can see that naturalist philosophers assume that there is a nature in the essence of the empirical world, and that this nature is unchanging. Accordingly, the things that are open to change and the essence that is assumed to be unchanging are different structures. Hence, 
it is thought that they need to be approached from different perspectives in respect to these different structures. Naturalist philosophers

“... call the elements of natural objects the 'nature', some calling it fire, others earth or air or water, others something else similar, others some of these, and others all of them." (Aristotle, Met. V 1014b32-35)

As Aristotle stated, the essence or nature of a being made of something like wood or bronze is wood or bronze. These materials exist in their essence, and it is their nature. Neither something made of wood can be wood nor can a statue made of bronze be bronze without them (Aristotle, Met. I 1014b26-34). For naturalists, arkhai such as water, fire, air or aperion, which they call the essence of being, constitute the nature of beings. Accordingly, everything that exists has its physis. In other words, there is an essence, a source behind everything that appears to us. For instance, Aristotle expressed that Thales' argument - that the essence of everything is water - is derived from his observation of the moist

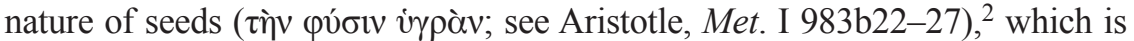
an indication that Thales determined the essence of beings as water and that the philosopher made a definition concerning their essence, that is, their nature. Accordingly, it is possible to interpret that Thales accepted that, regardless of what our senses perceive at first, their essence is different from what we perceive, and in this case, it is water. In other words, Thales is likely to be called a philosopher who implicitly put forth the distinction between appearance and truth for the first time, determining a different essence or nature from our senses.

Heraclitus more explicitly put forth this distinction between appearance and truth which was implicitly expressed by Thales. For Heraclitus

"although this Word is common, the many live as if they had a private understanding" (Heraclitus, DK B2) $)^{3}$

Heraclitus assumes that behind everything there is a common unchanging nature. However, while Heraclitus assumed such an unchanging nature, he also emphasized that there is an unchanging essence behind everything that changes, expressing that everything is in a state of change. Similarly, according to Heraclitus, everything is in a state of flux (Heraclitus, DK A6),${ }^{4}$ and everything scatters due to the swiftness and speed of change (Heraclitus, DK B91). ${ }^{5}$ However, there is an unchanging essence, a nature behind all this

"Indeed, from this sense of nature by the extension of meaning every essence in general is referred to as nature, because the nature of any thing is a kind of essence. From what has been said, then, the primary and proper sense of nature is the essence of those things which in themselves contain a source of motion [author's emphasis]." (see Aristotle, Met. V 1015a12-15).

2

"He derived his assumption, then, from this and also in the fact that the seeds of everything have a moist nature [author's emphasis], whereas water is the first principle of the nature of moist things."

Sextus Empiricus, Against the Professor, 7.132-33; Hippolytus, Ref. 9.9.3, from Graham, 2010:142-143.
4

"Heraclitus says, you know, that all things move and nothing remain still, and he likens the universe to the current of a river, saying that you cannot step twice into the same stream." (Plato, Crat. 402a8-10)

5

"It is not possible to step twice into the same river according to Heraclitus, or to come into contact twice with a mortal being in [the same] state. But by its swiftness and speed of change it [river] scatters things and in turn gathers them - or rather, not in turn or later, but at the same time - it comes together and separates, approaches and departs." (Plutarch, On the E at Delphi, 392b-c, in Graham, 2010:158-159) 
change. Everything we perceive through our senses is in a state of change, whereas, through our mind, we perceive logos as an absolute essence. To view this idea from another perspective, consider that logos indicates an absolute, universal and objective truth - unchanging for everybody - while our judgments regarding the things that appear are nothing but subjective interpretations. Heraclitus says that

"the waking have one common world, but the sleeping turn aside each into a world of his own" (Heraclitus, DK B89) ${ }^{6}$

In fragment B89 we can see that Heraclitus thinks that those who do not comprehend the universal withdraw into their own private worlds and interpret events within the framework of their subjective judgments and interpretations. However, to him, what really matters is to comprehend or to understand $\log o s$, i.e. the universal. As can be seen in his fragments, Heraclitus clearly made a distinction between the universal and the subjective. Nature represents the universal, and those who do not comprehend this universality represent the subjective. The subjective realm is where we function through our senses and everything is in a state of flux.

When we discuss Heraclitus' universal-subjective distinction within the scope of the physis-nomos concept relation, it would be possible to say that the universal, the essence or physis, is logos, and everything that is in a state of flux we will call subjective in time and thusly nomos. Although people live in accordance with certain rules (nomoi) they agree on before they comprehend the logos, they will realize that there is the single universal when they comprehend logos, and then they will live in compliance with the order valid for all times. Accordingly, physis will give us such a universal law.

We can find the traces of physis-nomos concept relation in the pre-Sophists period, in Democritus' philosophy as well as Heraclitus'. The primary-secondary distinction that regards qualities, made by Democritus, would then have an important place in founding the physis-nomos debates of the Sophists.

"For by convention, he says, sweet, by convention bitter, by convention hot, by convention cold, by convention colour, but in reality atoms and void. In other words the objects of sensation exist by agreement and opinion not in truth but only atoms and void really exists." (Democritus, B125-B126, F32a-F33) ${ }^{7}$

According to Democritus, the fact that something is sweet or bitter, hot or cold is a convention. All kind of opinions we form on the basis of our senses require an agreement. Nevertheless, what exists in essence and what is accepted as universal is that there are only the atoms and the void. Nothing is intrinsically hot or cold, bitter or sweet. Everything perceived through our senses is only a thing we form by means of convention. Accordingly, the things forming the essence or nature of something are qualified as primary, whereas others are considered secondary. In other words, everything obtained through our senses, such as bitter, sweet, sour, or hot is formed conventionally and is secondary, while the void and the atoms are the essence and are primary. In this case, saying that the thing is hot or cold does not reveal its essence. This is only an example of judgment that people find in common. So, our sense objects can only exist with cooperation that is not based on a belief or a written source. When these words of Democritus are interpreted through physis and nomos, atoms and space can be placed under the physis category, whereas sense objects can be placed under the nomos category. To Democritus, nomoi "are relative to us who perceive", and they require an emphasis on 
the contrast between truth and linguistic conventions. Moreover, a linguistic commonality on definition derives from our senses. However, this commonality cannot be considered as truth (Taylor, 2007:1-3). The distinction between appearance-truth or truth-convention (or belief), implicitly expressed by Thales and explicitly by Heraclitus and Democritus, is, just as Empedocles claimed ${ }^{8}$ within the framework of the theory of physics and it does not belong to political or moral theory. Nevertheless, with the emergence of the Sophists in the history of philosophy, this distinction started to be addressed within a political and moral framework (Taylor, 2007:3).

\section{Physis and nomos in the Sophists}

Although the distinction between nature and convention dates back to the period preceding the Sophists, the Sophists began to address this distinction within the political and moral framework of Ancient Greece. Whether in physical or political realm, the basis of this distinction is common. What exists in essence and what is intrinsic is physis, while the thing accepted through convention is nomos. In this regard, physis can be associated with the essence or truth, and nomos can be associated only with the appearance or senses. Before passing on to the Sophists' opinions on this matter, we need to take a look at the discussions on justice in the field of politics in order to explain their opinions, and get an answer to the question "how should we live?". The philosopher who explains this subject most comprehensively is Aristotle. ${ }^{9} \mathrm{He}$ touches upon two types of law, namely the particular and the general. The particular law is

“... established by each people in reference to themselves, which again are divided into written and unwritten, whereas the general law is based upon nature." (Aristotle, Rhet. 1373b2-6)

In this regard, physis gives us a law which is valid for everyone and binds to itself even those whose disposition is not in accordance with the natural justice and injustice principles. Giving an example from Empedocles, ${ }^{10}$ Aristotle suggested that a general law exists and that this law is valid for everyone. However, to Aristotle, this general law will sometimes create tension in practice. The example given by Aristotle is a clear indication of acceptance that a tension between nomos and physis exists, and in which, although it was forbidden, Antigone did burn Polynices, and Antigone obviously revealed that

Plutarch, On Superstition, 166 C, in Graham 2010:142-143.

Sextus Empiricus, Against the Professor, 7.135.37, in Graham, 2010:594-595.

8

When we look at the sense of Being in Empedocles' writings, it would be possible to say that the nomenclatures are considered as things that only people have in common. To give an example, Empedocles thinks that the nomenclatures given by people for concepts, such as 'vanishing', 'death', or 'existence', are just incorrect nomenclatures; he expressed that it is impossible for a non-existing thing to come into being or Being to exist (B11-12, B8-9). In addition, Empedocles describes that such thinking is silly, and such persons are infants without foresight.

9

Justice and injustice have been defined in reference to laws and persons in two ways, the particular and the general. By particular laws I mean those established by some or other people in reference to themselves, which are again divided into the written and the unwritten; by general laws I mean those based upon nature.

10

"But a universal precept, which extends without a break throughout the wide-ruling sky and the boundless earth." (Aristotle, Rhet. 1373b15-17) 
her action was fair according to physis. In this sense, it can be said that nomos is only an outer shell and that it is a concept completely abstracted from human nature (Johansen, 1998:112). But for Sophocles, the following can be said about physis:

"For neither to-day nor yesterday, but from all eternity, these statutes live and no man knoweth whence they came." (Aristotle, Rhet. 1373b12-13)

The reflection on the debate about the physis-nomos concept relation in the political realm and in the realm of morality was intensely discussed among the Sophists. The answers to the questions of how should we live or how can a sense of universal justice be established were formed through debates on the physis-nomos concept relation. In this debate some Sophists, such as Hippias, Antiphon, and Callicles, tried to establish the idea that physis is superior to nomos, whereas we see that Critias addressed nomos as the opposite of physis, and suggested that the universal justice can be provided through nomos. It would be possible to say that Protagoras of the Sophists did not completely refuse physis in the physis-nomos debate, but he still preferred nomos over physis. In this part of the study, I will focus on the aforementioned Sophists, explore how they discussed the physis-nomos debate and I will try to provide answers to the questions addressed in the first part.

The first Sophist who established one of the main discourses on this debate, and was at the same time on the side of physis, was Hippias. Hippias thought that life is fairer and more universal when it is organized in accordance with physis and that people will live according to the set of rules that will be valid every time, even without an order established, because of the similarities between different people.

"Gentlemen, he said, who are here present, I regard you all as kinsmen and intimates and fellowcitizens by nature, not by law: for like is akin to like by nature, whereas law, despot of mankind, often constrains us against nature." (Plato, Prot. 337c-d)

According to Hippias, nomoi are systems of law generated through negotiation between people. These rules are not universal, because they apply to specific time and location, and to people who are members of a particular community. According to physis, people are similar to each other or are related to each other, whereas nomos almost divides people by pressuring physis (Reale, 1987:179). According to Hippias, treating people as if they were different, even though they are similar, are means of implementation of an unreal principle. This case reminds us of Democritus' distinction of the primary and secondary quality; of similarities between people as well as their equalities which are established through physis so that, as an universal principle, there are no essential differentiations between people. For this reason, Hippias enquired about how anyone considered nomoi to be a very important subject (McKirahan, 2010:406). Similarly, people set laws into effect, repeal them and change them by amending. Nomoi are the rules established by people themselves, and it is again in people's power to amend and substitute them. In addition, since these rules are established by people, they vary from society to society and within different periods of time. Yet physis cannot be changed in line with wishes and desires of people. Whatever nature is, people live in compliance with it and such life brings along harmony and justice. Accordingly, every person is connected to the same single nature, and this nature is destroyed when human beings try to subdue it by nomos, and thus the universal principle among people is abolished in this way. 
Deepening the way led by Hippias, Antiphon discussed physis and nomos more comprehensively.

"For the works of law are factitious, whereas those of nature are necessary; and the works of law, being conventional, are not natural, while those of nature, being natural, are not conventional. Thus one who transgresses the laws, if he eludes those who agreed on them, also escapes shame and punishment, but if not, he does not. But if he undertakes to violate what is possible of things innate in nature, even if he eludes all men, the evil that results is no less. It is no more. For he is harmed not because of opinion but in truth." (Antiphon, F46a; B44) ${ }^{11}$

According to Antiphon, law is factitious. Since the imperatives of laws are produced by people through convention, they are not natural. Therefore, they are valid for a specific place or time. However, imperatives of nature are valid for all times and they do not emerge or can be changed in a certain place or time as a result of people's convention. Moreover, according to Antiphon, a thing considered evil by physis may not be always deemed evil by nomos. In other words, the fact that a thing is deemed evil by nomos becomes possible only through the fact that evil is known by people who agreed on the law. Thus, Antiphon differentiates naming evil as evil according to physis or nomos. According to nomos, evil is denoted as evil when it is visible and known to everybody. However, evil is denoted as evil even if nobody knows it according to physis. The harm or evil needs to be considered in terms of truth, rather than things that people agreed on. Similarly, damage or evil, determined according to physis, are not identified by opinions in terms of truth, and they can be referred to as evil or harmful although nobody knows or sees it since the law is universal for all times and places. In this context, Antiphon notes that physis carries this universality (or the demand for truth) within itself. Here a significant distinction arises on the epistemological level. A new tension rises between nomos, occurring through agreement, and its extension in knowledge as belief or opinion, and physis with its corresponding truth in the knowledge. When it is considered that the ground Antiphon seeks is the universal ground, we may conclude that he does not seek belief but truth because he established this universality on the ground of physis. In this debate he searched for the universal information valid for everybody, everywhere, and in any time. He aimed to establish a sense of universality intrinsically obtained by people. Antiphon specified that this could only be possible with physis, because according to him nomos is insufficient in providing this universality.

"The advantages accruing from laws are chains upon nature, but those from nature are free." (Antiphon, F46a; B44) ${ }^{12}$

While the law restricts nature, nature is the one that is free. Justice established through the law is valid for a specific time and place, whereas nature is the same everywhere. The law brings justice only to a specific group of people, whereas nature provides justice for every person.

Antiphon's idea, that not law but nature brings justice to everybody, can be considered a critique of practices of that period. Similarly, considering how justice is established in the courts under the conditions of the pertaining period, we see that the art of rhetoric has an important place. However, elocution through this art might be considered a critique of the establishment of justice, on the basis of the opinion that even someone doing an injustice is some-

11

Oxyrhynchus Papyri XI $1364+3647$ fr. 1, in Ibid.

12

Graham, 2010:812-813. 
times declared innocent at court. Therefore, the real offenders may impose their innocence if they practice the art of oratory well at the courts where not nature but laws are applicable (Antiphon, F46a; B44). ${ }^{13}$ Thus, an offender is declared innocent according to the laws with respect to physis. This may be regarded as an indication of why Antiphon considers law and nature as opposites. What is universal according to nature varies within the scope of the power of the person according to law. However, to Antiphon, the obligatory, universal, and genuine law is the law of nature.

The fact that Antiphon based the sense of universality on nature did not force him to discriminate people in terms of origin or race. Explaining that not the people living in a specific region, but all the people in the world have the same nature, he did not make a distinction between a Greek and a foreigner. This idea led Antiphon to a sense of a cosmopolitan human being.

"The laws and customs of those who live nearby we know and respect; those people dwelling far away we neither know nor respect. In this way we become barbarian to each other, since in all ways are all equally fitted by nature, at least, to be both barbarians and Greeks. It is possible to examine some of the features that are naturally necessary to all men; and it is possible [to learn from these things]. And in all such things none of us has been distinguished as either a barbarian or a Greek." (Antiphon, F46b B44) ${ }^{14}$

According to Antiphon, it is not possible to make a distinction between people as they have the same nature. People have become factitiously estranged to each other in their relations and separated unnaturally. Nevertheless, every human being breaths the same air, hears the same sounds, sees with their eyes, smiles when she is happy and cries when she is sad. All these things happen because of the same nature that all the people have in common. The fact that people do not have any differences in terms of their nature indicates that distinctions between them do not come from nature, that is, that these distinctions are factitious. To Antiphon, all people are equal and the source of this equality is physis. Nomos causes factitious distinctions between people as a set of rules that destroy universality brought by physis, and nomos emerges as conventional. Hence, a sense of universal justice can only be established through physis and people can live more happily in an environment where physis is dominant.

Unlike Antiphon, who considered physis superior to nomos and expressed that people are equal and that this equality can only be provided through physis, Callicles suggested that people are intrinsically unequal. On the side of physis in the physis-nomos debate, Callicles did not place the nature as the basis of equality as Antiphon did, though he accepted it as an universal basis. To him, there is no equality in nature. Equality is a concept imposed by citizens. Equality ensured by law is indeed pressure that is enforced upon the weak majority by the strong minority. Similarly, the weak ones make laws for their own interests. They try to subdue those who are stronger than them by means of law so that they do not win and make them scared. According to Callicles, this is the reason why equality is a concept accepted mainly by the weak ones. As examples can be seen in nature itself (relations between animals), people are intrinsically unequal. It is clearly seen in nature that the strong ones always dominate over the weak ones. However, the majority puts pressure on the minority and does not let the minority rule thanks to laws. Thus, what is right according to nature is that the best and the wisest ones of the minority rule over the weak (Plato, Gorg. 489e). Similarly, the laws made by people collectively prevent the use of abilities coming from nature (Osborne, 2004:122). What is just and what establishes justice, and what conforms to nature, is the political order where the strong rule the weak: 
"But I suppose the makers of the laws are the weaker sort of men, and the more numerous. So it is with a view to themselves and their own interest that they make their laws and distribute their praises and censures; and to terrorize the stronger sort of folk who are able to get an advantage, and to prevent them from getting one over them, they tell them, that such aggrandizement is foul and unjust, and that wrongdoing is just this endeavour to get the advantage of one's neighbours: for I expect they are well content to see themselves on an equality, when they are so inferior." (Plato, Gorg. 483a-b)

Within the scope of physis-nomos, the ideas suggested by Callicles can be regarded as an emphasis on the importance of establishment of justice according to nature, the necessity to live in an universal sense, suitable to their nature, though it is not equalitarian; and it can be regarded as a critique of the sense of justice established through convention. Living together can be founded universally on the basis of physis. Besides showing people what they deserve, physis is the one that will establish absolute justice that does not claim equality, as it is unchanging and universal. Hence, an order valid for all times, places, and people will emerge.

The aforementioned Sophists, who were thinking about how people can live together in a better way, remarked that such living is possible only through physis. Their answer to the question "how should we live?" is to live according to nature, according to what is given in nature. Nature or physis is presented as the universal and absolute criterion. The sense of justice in a society emerging on the basis of physis will not vary by person or by place under any conditions and it will not be in a continuous state of change. In the context of obligation, justice will be intrinsically established by its essence. Therefore, a sense of universal justice will be presented and discriminations caused by nomos will be eliminated. As it is by Antiphon's idea, people can be regarded equal or, as it is by the idea suggested by Callicles, they cannot be regarded as equals. Although there is no consensus on the sense of equality, living together on an universal basis needs to be ensured only by referring to nature and by having physis as the basis.

Besides those who try to ground the universality and justice criteria on physis, there are also thinkers who suggested that people can live together on the basis of nomos. The reason why these philosophers opt for nomos is similar to the reason of those defending physis, and they likewise aim to establish justice universally. Accordingly, just like physis, nomos too constitutes a basis for living together justly. Critias, one of the leading defenders of this idea, also suggested that the universal conditions for living together can be provided through nomos. According to him, there is only disorder and chaos in an environment where physis is dominant.

"There was a time when human life without order,

On the level of beasts and subject to force;

When there was no reward for the good

Or punishment for the bad.

And then I think humans established

nomoi as punisher, so that justice would be the mighty ruler

Of all equally and would have violence (hubris) as its slave,

And anyone who did wrong would be punished." (Critias, DK 88B25 1-8) 
In this fragment, where Critias mentioned the first period in which physis of humanity is dominant, he argued that this period was chaotic, animalistic, and that people were not safe under any conditions. No justice and no universal rules were available among people in a society in which a great chaos and disorder prevailed. Following Critias' words, neither goodness is rewarded nor is evil punished in such an environment. Therefore, the dominance of nature over the order causes disorder and injustices and prevents the establishment of a sense of universal justice. He thought that establishment of an order, where a sense of universal justice exists, is only possible through nomos. In the pre-law period, while people lived in disorder by using force on each other, just as in nature, justice was established pursuant to the law - those committing a crime were punished and those doing good were rewarded. The following line:

“... and then I think humans established nomoi as punisher, (...) anyone who did wrong would be punished."

is an indication that Critias perceived physis as a state of disorder and chaos and identified it as a situation in which injustice prevails. When the dominance of nomos began, it was not possible to find a situation in which injustices from the period of physis prevailed. To him, to say that life is bearable without nomos is not probable (McKirahan, 2010:417). It is nomos which brings justice, and it makes it possible for people to live together by enabling the idea that everybody is equal. It is nomos which establishes order, justice, and universality.

As McKirahan stated, besides the Sophists, there are thinkers who suggest that the definitions of physis and nomos can substitute each other. Interestingly, in this substitution we see that nomos, rather than physis, is universal, and that it is not physis but nomos that is suggested to be unchanging (McKirahan, 2010:422).

"All the life people in cities both great and small is run by physis and by nomoi. Of these, physis is without order and private to each individual but the nomoi are common, in order, and the same for all... The nomoi, on the other hand, desire what is just and good and advantageous, and they aim for this and when it is found, this is published as common command, equal and similar for all and this is nomos." (Pseudo-Demosthenes, 25.15-16.20)

In addition, quoting from Supplices by Euripides, McKirahan points out Euripides' argument that a society under the dominance of nomos is hateful and, according to him, nomos puts an emphasis on universality and brings a sense of equal justice whether it is applied to the weak or strong when it is written. In other words, it ensures a universal justice that applies to everyone equally. It is a common system of rules that applies both to strong and weak human beings.

It would not be wrong to claim that there is no deep and significant difference between those placing nomos on the basis of the form of just living, and those placing physis in its place. Similarly, we can say that Critias' argument regarding nomos was also made by Antiphon for physis. Arguing that punishment for injustices and evil can be carried out on different grounds, both Sophists tried to comprehend a sense of universal justice. Antiphon suggested that whether or not injustices and evil things committed by people were unjust can be determined by physis rather than nomos, whereas Critias considers nomos as an universal tool of punishment. Hence, from the perspective of both Sophists, it is possible to say that the concepts are united on the basis of a sense of justice and that they are used accordingly to set universal norms. 
One of the most important ideas, suggested as a combination of these two opposing ideas in the physis-nomos debate, belong to Protagoras. Answering the question "How should we live?", Protagoras determined physis to be a basis for his approach, but also suggested that this sense of universal justice cannot be established without nomos. In other words, while not giving up on physis completely, Protagoras supported the nomos in the debate, suggesting that justice cannot be established without nomos. We can clearly see, in the context of the Prometheus myth, addressed in the dialogue Protagoras by Plato (320c-322d), that the thinker has placed physis at the basis of the approach established with nomos. According to the myth, there are two senses that are necessary for people to live together. Zeus ordered Hermes to equally distribute among people the sense of shame (aidos) and the sense of justice (dikê). Accordingly, people will get equal shares from the art of politics or political virtue thanks to these two senses making it possible for humans to live together. Survival and continuity of a polis is only possible when everybody gets their shares from the senses of shame and justice. Considering the myth, it would be possible to think that Protagoras approves the idea that people have a specific nature when they have the senses of shame and justice. However, the fact that people have these senses is not sufficient for them to live justly. The nature in people is functional thanks to nomos. Ensuring universality without nomos and establishing a just society with functionality of physis is not possible. According to Protagoras, who relates physis and nomos, it is nomos which will enable people to finally live together. The senses of shame and justice in people may be regarded as the potentials that will actually become functional with nomos. In each polis, nomoi will make these potentials fulfilling. For Protagoras, aidos and dikê provide people with an opportunity for a civilized life, while nomos creates the model of civilized life (McKirahan, 2010:418). Protagoras' sayings on the education of people indicate that he placed nature as the basis, but nature is not enough for a good education.

"In the work entitled The Great Speech Protagoras said: (F5a) Instruction requires natural ability and practice and (F5b) Men must learn starting from childhood." (Paris Anecdotes, 1.171.31, in Graham, 2010:710-711)

Since natural abilities are not sufficient for education, the aidos and dikê in people's nature are not sufficient for them to live together, either. As there is no practice or a natural ability that will not be made functional through education since early age, it is out of the question that people live together without nomos. Taking its aforementioned meaning into consideration, nomos might be regarded as a basis for the creation of common life by being collectively realized by people living in the society where it is in effect.

Aforementioned Protagoras' idea, which he suggested as a basis for the composition of a society, overlaps with his idea about a men-measure (homo mensura), providing a basis for his epistemology.

"Of all things the measure is man, of things that are that they are, of things that are not that they are not." (Protagoras, A14; F1e) ${ }^{15}$

Rules may vary by society or time, in a place where people are the criteria of everything. Hence, although Protagoras assumes that man has a nature in terms of dikê and aidos, it is nomos that will bring out justice as a potential 
and it will make it valid for the whole society. In other words, the fact that people intrinsically have senses of shame and justice is not enough for a just life and for a society regulated by justice. Laws are necessary to regulate relations between people and for a society to be more harmonious in its continuity.

Although we see that Protagoras' idea of universality, and even equality, is established through physis, this idea requires laws. In other words, it would not be wrong to suggest that Protagoras had a sense of a better and more virtuous society in his mind, though laws vary by polis or society. Similarly, to Protagoras,

“... for our neighbours' justice and virtue, I take it, is to our advantage, and consequently we all tell and teach one another what is just and lawful." (Plato, Prot. 327b)

Those who know what compliance with justice and laws means should teach them to the others. Those who teach them are the ones who have more information about them, and know what they really are. It is possible to say that a sense of universal justice can be created in a society where they are known. Therefore, life in compliance with laws is important since they are prepared by more virtuous people, although laws vary by society or time (Plato, Prot. 326d-328a). Each polis makes its laws in order to show their citizens the way to virtue (McKirahan, 2010:418). According to Protagoras, a more virtuous and just order will emerge when people of virtue lead society. When he described himself as a person who can teach others virtue and show them what just is (Plato, Prot. 328b), he considered a human being to be a criterion for everything; yet he can claim that there are people who transfer virtue and justice by knowing what they are, and thus he thought that a more virtuous and just society can emerge. It would be possible to suggest that Protagoras is latently in search of a sense of universal justice, considering the fact that deep down he thought about the existence of wiser or more virtuous human beings. With this in mind, he pointed out that there are people who know what universal wisdom or virtue really is and he claimed that society needs to be formed accordingly.

\section{Conclusion}

The debate regarding what basis a human-made world should be built upon is one of the most important topics addressed since the archaic age. We can analyse this debate in two periods, the period of ontologically based debate, and the period of politically/morally based debate. Although the debate concerning the concept pair of physis-nomos is considered to be one of the basic topics, addressed by the Sophists within the most general framework, as it is touched upon in the first part of this paper, it would be possible to say that its origin dates back to the period preceding the Sophists. The truth-appearance or truth-convention (belief) debate, which was discussed within the scope of physical theory in the pre-Sophist period, was brought into the moral and political realm via the Sophists, and the debate was shaped within the framework of the physis-nomos concept relation. While the focus of that debate is the question of arche, an ontological and cosmogonical concept in the pre-Sophist period, within the Sophists's discourse the focal point became a human being and it shifted into the political and moral debate in the context of the question about the basis upon which human beings build their world. However, it is possible to claim that the transformation of debate from 
the concept pair of truth-appearance into the concept pair of physis-nomos caused a clearly distinguished contrast in the concept pair of truth-appearance to be attributed to the concept pair of physis-nomos, and the debate between the Sophists to be interpreted as a debate of opposing views. Considering the comments on this matter made by the Sophists, we see that they did not discuss the concepts by distinguishing them clearly; rather, they tried to focus on two concepts, namely justice and universality. The debate between them is related to how people base the world on a sense of universal justice. In this debate, those considering nomos as a changing thing in place and time constitute universality through nature, claiming that physis is valid for everybody to the same extent. Further, there are the ones seeking universality through nomos by thinking that nomos will bring equal rights to everyone and thus improve a sense of common and universal justice for everyone. Those defending both physis and nomos have separated these concepts from their lexical meanings and their origins in the pre-Sophist period. It was suggested that there might be differentiations even within the same concept (e.g. physis) in respect to the order emerging in society. To give an example, the fact that Antiphon, who defended physis over nomos and claimed that the concept of nomos brings justice only to a certain group of people and that justice for everybody is possible only through physis, pointed out that he was in search for both justice and universality and that he found its roots in physis. Moreover, expressing that all people in the world have the same nature with physis, Antiphon asserted a sense of a cosmopolitan human being and argued that no distinction can be made between people in terms of their nature. Although the idea of Callicles, who defended physis, was similar to Antiphon's on the basis of universality and justice, they differed in terms of the idea that people are intrinsically equal. In a similar vein, according to Callicles, equality between people is out of question according to physis, but people may build a sense of universal justice when they live in compliance with their nature which causes inequality. Hence, despite the differences in regard to the state of human being in an environment, physis is dominant in the ideas about how justice is established among people and for the Sophists defending physis within the scope of a sense of universal justice, the main common emphasis was on justice and universality.

Emphasis on universality and justice is regarded as the focal point of the debate by not only those defending physis but also by those defending nomos. For instance, the ideas about nomos pertaining to Critias, one of the philosophers who preferred nomos over physis, cannot be positioned in a different place from justifications of those defending physis. Critias asserted that people are not safe in the state of nature and that they live in big chaos and disorder, and he explained that universal rules and justice are invalid in such a state. By claiming that physis creates an atmosphere of chaos and disorder and causes injustice and unfairness, he asserted that people can reach a solution only through a society founded on the basis provided by nomos; physis brings injustice or unfairness into communities. As Pseudo-Demosthenes stated, it is not physis but nomos which is defined as the basis for the universal and common injustices. In other words, nomos makes it possible to put forth a sense of universal justice for everyone.

To conclude, the debate of the Sophists discussed in this article, regarding what basis people should live on, may be considered as an indication that the concept pair of physis-nomos cannot have certain conceptual schemas. The quest of the Sophists regarding the debate is implicit in their definition of the 
concepts. As is seen in the depth of the debate, it should not be overlooked that the Sophists, while discussing what concept human beings need to build the world with, aimed to establish justice, universally regarded as the golden concept of that period. In this regard, definitions of the concept pair of physis-nomos should not be interpreted within an enclosed and single framework but through multiple frameworks or a pluralistic framework.

\section{References}

Aristotle (1926). Art of Rhetoric. Harvard: Harvard University Press.

Aristotle (1933). Metaphysics. Harvard: Harvard University Press.

Barney, R. (2006). "Sophistic Movement”, in: Mary Louise Gill, Pierre Pellegrin (eds.), A Companion to Ancient Philosophy. Oxford: Blackwell Publishing, pp. 77-97. doi: http:// dx.doi.org/10.1002/9781444305845.ch5.

Empedocles (1908). The Fragments of Empedocles. Chicago - London: The Open Court Publishing Company.

Graham, D. W. (2010). The Texts of Early Greek Philosophy. The Complete Fragments and Selected Testimonies of the Major Presocratics, Part I-II. Cambridge: Cambridge University Press.

Johansen, K. F. (1998). A History of Ancient Philosophy. From the Beginning to Augustine, London: Routledge. doi: http://dx.doi.org/10.4324/9780203979808.

Kerferd, G. B. (1981). The Sophistic Movement. Cambridge: Cambridge University Press.

McKirahan, R. (2010). Philosophy before Socrates. An Introduction with Texts and Commentary. Indianapolis: Hackett Publishing Company.

Osborne, C. (2004). Presocratic Philosophy. A Very Short Introduction. Oxford: Oxford University Press.

Plato (1924). Laches. Protagoras. Euthydemus. Meno. Cambridge (MA): Harvard University Press.

Plato (1925). Lysis. Symposium. Gorgias. Cambridge (MA): Harvard University Press.

Plato (1926). Cratylus. Parmenides. Greater Hippias. Lesser Hippias. Cambridge (MA): Harvard University Press.

Reale, G. (1987). A History of Ancient Philosophy I: Form the Origins to Socrates, New York: State University of New York Press.

Taylor, C. C. W. (2007). "Nomos and Phusis in Democritus and Plato", Social Philosophy and Policy Foundation 24 (2/2007), pp. 1-20. doi: http://dx.doi.org/10.1017/ s0265052507070148.

\section{Nihal Petek Boyaci Gülenç}

\section{Istraživanje o raspravi physis-nomos: sofisti}

\section{Sažetak}

Jedna je od glavnih rasprava vezanih uz temu "povijesnog svijeta ona o odnosu pojmova physis $i$ nomos. Historijski izvori ove rasprave mogu se pratiti sve do 5. i 4. stoljeća pr. Kr. Tijekom ovog razdoblja mnogi su filozofi, povjesničari i autori iznosili različite ideje o ovoj temi. Neki od njih su smatrali da je physis superioran nomosu dok je za druge nomos bio superioran physisu. Glavni je problem u ovoj raspravi sklonost stabiliziranju napetosti između ovih dviju sfera povlačenjem jasnih granica među njima. U tom smislu trebamo postaviti dva važna filozofska pitanja. Prvo, je li moguće reći da physis $i$ nomos imaju jasne konceptualne sheme? Drugo je pitanje vezano za prvo te razmatra može li se napetosti između physisa $i$ nomosa prići 
na fiksan način ili ne. Ovaj članak istražuje pitanja rasprave o odnosu physis-nomos iz perspektive sofista i drugih mislitelja toga doba. Istraživanje se temelji na okviru koji ljudi koriste pri konstituiranju svijeta te će razmotriti u kakvu vezu physis $i$ nomos trebaju biti dovedeni.

Ključne riječi

priroda, konvencija, zakon, univerzalno, pravednost, predsofisti, sofisti

\title{
Nihal Petek Boyaci Gülenç
}

\section{Forschung der Physis-Nomos-Debatte: Sophisten}

\section{Zusammenfassung}

Eine der Hauptdiskussionen zum Thema „,menschengemachte Welt“ ist die Physis-NomosDebatte. Historische Wurzeln dieser Debatte können bis ins fünfte und vierte Jahrhundert v. Chr. zurückverfolgt werden. Während dieses Zeitraums brachten zahlreiche Philosophen, Historiker und Autoren verschiedenartige Ideen zu diesem Thema an den Tag. Einige von ihnen betrachteten die Physis als dem Nomos überlegen, während andere den Nomos als der Physis überlegen ansahen. Das Hauptproblem, welches innerhalb dieser Diskussion auftaucht, ist die Neigung, die Spannung zwischen diesen beiden Sphären zu stabilisieren, indem man feste Grenzen zwischen ihnen zieht. In dieser Hinsicht müssen wir zwei wichtige philosophische Fragen aufwerfen. Erstens, ob es möglich ist zu sagen, Physis und Nomos hätten scharf umrissene konzeptuelle Schemata? Die zweite Frage ist mit der ersten verknüpft und handelt davon, ob sich die Spannung zwischen Physis und Nomos in einer festen Art und Weise behandeln lässt oder nicht. Der Beitrag diskutiert diese Fragen aus der Perspektive der Sophisten sowie andere Herangehensweisen der zeitgenössischen Denker an die Physis-Nomos-Debatte. Er basiert auf einer Ideenstruktur, die die Menschen während der Konstituierung der Welt nutzen, und wird einschätzen, in was für einem Zusammenhang Physis und Nomos stehen sollten.

\section{Schlüsselwörter}

Natur, Konvention, Gesetz, das Universelle, Gerechtigkeit, Vorsophisten, Sophisten

\section{Nihal Petek Boyaci Gülenç}

\section{Une étude sur le débat Physis-Nomos : les Sophistes}

\begin{abstract}
Résumé
Le débat physis-nomos a été l'une des discussions principales ayant trait au thème du " monde humain fabriqué ». Les racines historiques de ce débat remontent aux cinquième et quatrième siècle AEC. Durant cette période, de nombreux philosophes, historiens et auteurs ont mis à jour diverses idées à ce sujet. Certains ont considéré que le physis était supérieur au nomos, tandis que d'autres ont pensé que le nomos était supérieur au physis. La tendance à vouloir atténuer les tensions entre ces deux sphères en posant entre elles des limites fermes est le principal problème abordé dans cette discussion. C'est à cet égard que nous devons nous poser deux questions philosophiques majeures. Premièrement, est-il possible d'affirmer que le nomos et le physis ont des schèmes conceptuels bien définis? La seconde question est rattachée à la première et il s'agit de savoir si les tensions entre le physis et le nomos peuvent-elles, oui ou non, être traitées de manière égales et uniques. Ainsi, cet article aborde la question du point de vue des Sophistes et à partir d'approches de penseurs contemporains s'intéressant au débat physisnomos. Il est basé sur la structure que les humains adoptent pour constituer un monde et tente également d'évaluer la manière dont le physis et le nomos devraient être mis en lien.
\end{abstract}

\section{Mots-clés}

nature, convention, loi, universel, justice, pré-Sophistes, Sophistes 